EESTI NSV TEADUSTE AKADEEMIA TOIMETISED. XVII KÖIDE

KEEMIA * GEOLOOGIA. 1968, Nr. 3

ИЗВЕСТИЯ АКАДЕМИИ НАУК ЭСТОНСКОЙ ССР. ТОМ ХVII

Химия * ГЕОЛогня. 1968. 초 3

D. OBRUCHEV, E. MARK-KURIK

\title{
ON THE EVOLUTION OF THE PSAMMOSTEIDS (HETEROSTRACI)
}

After our joint paper (1965) has been published, new materials of psammosteids have been collected in the Baltic area, and a number of new restorations have been made, and some of the older ones modified. The purpose of the present paper is to give a concise account of the evolution and ontogenetic development of this interesting group of fossil Agnatha, together with some data on their morphology. This study is based solely on the material from the Main Devonian Field (Baltic states, Leningrad, Pskov and adjacent regions), which is the chief area of development of the psammosteids in the Soviet Union, as well as in the world in general.

In the Givetian and Frasnian of the Main Devonian Field the psammosteids are represented by seven genera, comprising numerous species. Their fossil remains consist as a rule of isolated plates and scales. Only in very few cases same of the plates have been preserved in natural connection. Most irequently the branchial plates are met with, so that many species have been founded only on these plates. Lateral and ridge scales are rather common. Dorsal and ventral plates are twice as rare as the branchials. Other plates: rostrals, pineals, orbitals, postorbitals, cornuals and the anterior plates of the ventral carapace, have been discovered only in a few occasions.

Although the material of many forms is rather insufficient, attempts have been made to make restorations of a number of psammosteids (Fig. 1). In making the restorations Drepanaspis gemuendenensis, recently described in great detail by Gross (1963) was used as a standard of comparison. Drepanaspis and the psammosteids differ in some respects, but there is a great similarity in the arrangement of the plates in these forms. Furthermore, some plates of the psammosteids: rostrals, orbitals, postorbitals, cornuals and the medial marginal closely resemble in form those of Drepanaspis. The psammosteids differ from Drepanaspis mainly in the shape of the branchials and in the structure of the dorsal and ventral plates.

A number of restorations have already been published (Obruchev and Mark-Kurik, 1965). Some of them, those of Tartuosteus maximus MarkKurik, Pycnosteus tuberculatus (Rohon), Ganosteus stellatus Rohon and Psammosteus bergi (Obr.) are now presented in a somewhat modified form. Restorations of Schizosteus heterolepis (Preobr.), Tartuosteus (?) Iuhai Mark-Kurik, Ganosteus artus Mark-Kurik, Psammolepis toriensis (Mark-Kurik) (formerly referred to Schizosteus), Psl. abavica Mark- 
Kurik, Psl. paradoxa Ag., Psl. alata Mark-Kurik, Psammosteus livonicus Obr., Ps. praecursor Obr. and Ps. maeandrinus Ag. are new. They are based on the material already published (Obruchev and Mark-Kurik, 1965), as well as on the new material described in a forthcoming paper by Mark-Kurik (1968). The restorations, though schematic, demonstrate the great variety in the body form of the psammosteids and its changes within their genera.

The Givetian and early Frasnian psammosteids were large forms. If the proportions of their body and tail were more or less similar to those in Drepanaspis, their dimensions may be considered as follows. The smallest forms, Schizosteus heterolepis and Sch. striatus (Gross) from Pärnu and Narova beds seem to have had a length of about $60 \mathrm{~cm}$. The length of the most Givetian and early Frasnian psammosteids varied probably from 70 to $90 \mathrm{~cm}$. The largest forms, Tartuosteus giganteus (Gross), T. maximus, T. (?) luhai, Pycnosteus tuberculatus, Psammolepis proia MarkKurik and Psammosteus bergi with the length of about $1 \mathrm{~m}$ and more existed in Aruküla and Burtnieki times. The length of some of the latter (Tartuosteus, Pycnosteus) could possibly reach $1.5 \mathrm{~m}$.

In most psammosteids the body was broad. The width of the giant Tartuosteus maximus and Pycnosteus tuberculatus was more than $1 \mathrm{~m}$, owing to their very extended branchials. Among the species of Schizosteus and Psammosteus some comparatively slender forms are known. The dorsal side of the psammosteid carapace was moderately convex, the ventral one was considerably convex in Schizosteus, Tartuosteus, Pycnosteus and Ganosteus. In Psammolepis the ventral side may have been nearly as flat as the dorsal one, or even flatter in its median part (Fig. 2).

It is possible to divide the Givetian and early Frasnian psammosteids in two groups on the basis of the structure of their dorsal plates. In Schizosteus, Tartuosteus, Pycnosteus and Ganosteus these plates are without tesserae, and their growth centre lies in the centre of the plate. In most forms they are more or less circular in shape. In the second group the oblong dorsal plates are covered partly (in Psammolepis) or entirely (in Psammosteus) with tesserae, and their growth centres are situated, with some exception, anteriorly.

In some psammosteids the pattern of the sensory canals on the dorsal plates is known (Fig. 3). In Tartuosteus, Psammolepis and Psammosteus it is very asymmetrical and consists of two medial dorsal canals and $1-3$ transverse commissures. In Psammosteus bergi and Ps. megalopteryx (Trd) lateral dorsal and possibly pineal canals are also present. The sensory canals in the young individuals of Ps. bergi differ in their pattern from those of the adult ones. The medial dorsal canals and the transverse commissures $\left(\mathrm{cd}_{\mathrm{a}}, \mathrm{cd}_{\mathrm{b}}\right)$ are shorter and more widely spaced. The lateral dorsal and pineal(?) canals are not developed. The pattern of the sensory canals on the dorsal plates of Psammosteus is like that in pteraspids.

The more or less circular dorsal plates in Tartuosteus, Pycnosteus and Ganosteus are associated with wide and long branchial plates. In Schizosteus and Psammolepis two kinds of branchials are found, long and narrow ones and long and wide ones. In earlier members of Psammosteus the branchial plates are wide and relatively long, in later ones they are extremely short and wide. The distal tips of branchials are directed as a rule backwards or sidewards. Only in a few forms: Schizosteus splendens (Eichw.), Pycnosteus pauti Mark and P. tuberculatus, they are turned forwards. 

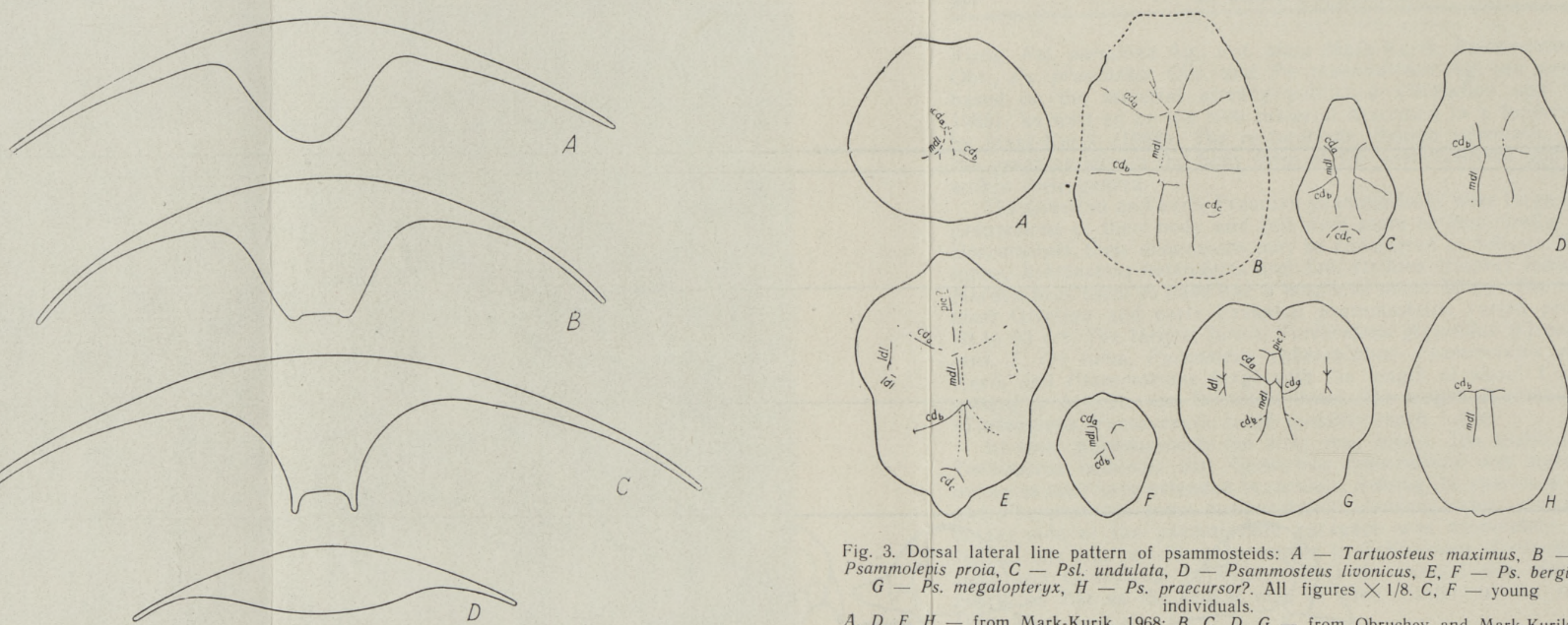

Fig. 3. Dorsal lateral line pattern of psammosteids: $A-$ Tartuosteus maximus, $B$ sammolepis proia, $C-P s l$. undulata, $D-$ Psammosteus livonicus, $E, F-P$ s. bergi, $G-P s$. megalopteryx, $H-P s$. praecursor?. All figures $\times 1 / 8 . C, F-$ young

$A, D, F, H-$ from Mark-Kurik, 1968; $B, C, D, G$ - from Obruchev and Mark-Kurik, 1.965 ( $G$ - modified).

Fig. 2. Diagrammatic cross-sections of carapace: $A-$ Tartuosteus giganteus, $B-$ Pycnosteus palaeformis, $C-P$, tuberculatus, $D-P$ sammolepis. $A-C-$ from Obruchev and Mark-Kurik, 1965.

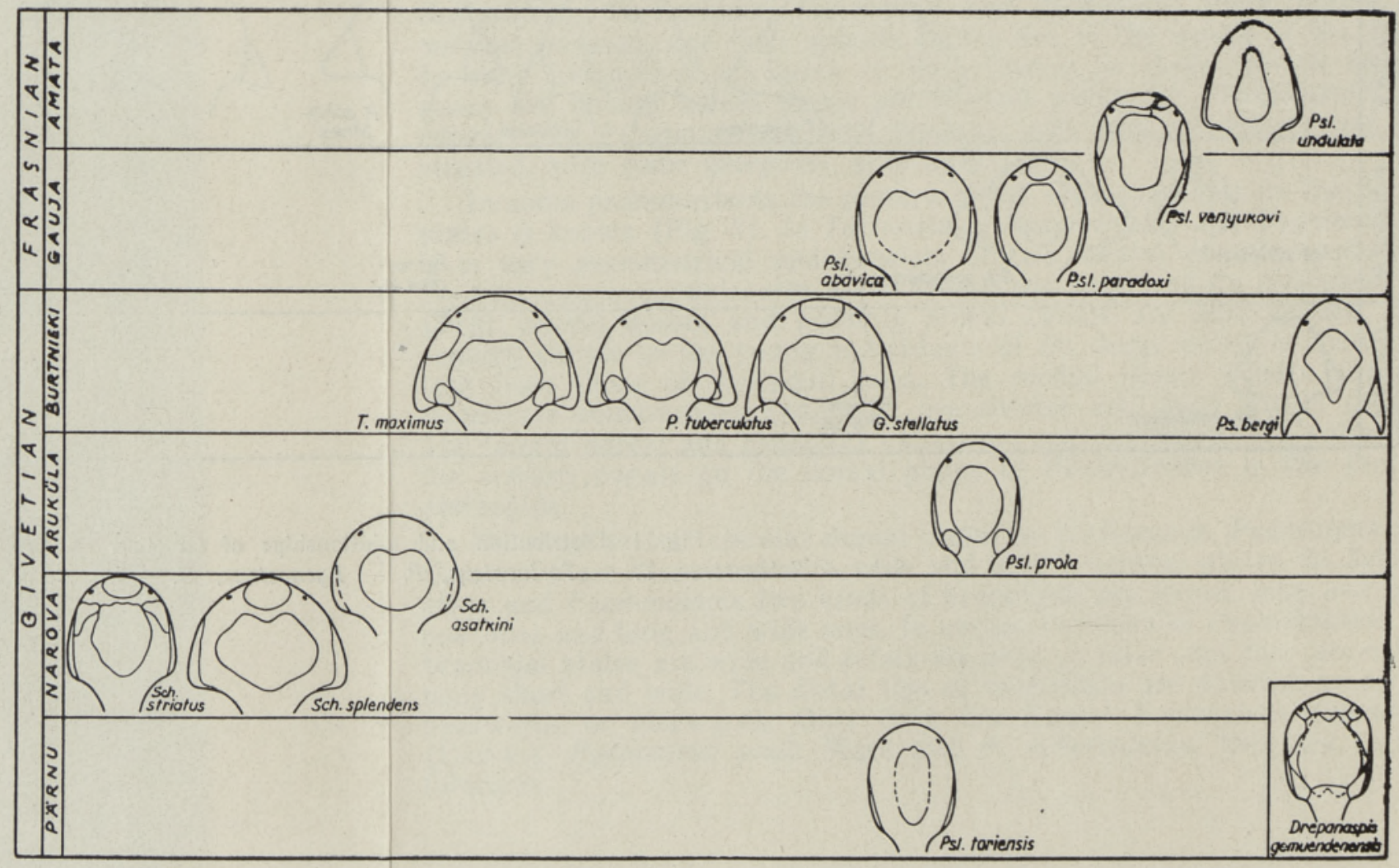

Fig. 4. Restorations of young psammosteid individuals: Schizosteus, T. - Tartuosteus, P. - Pycnosteus, Drepanaspis gemuendenensis after Gross, 1963. 
The ventral plates of the psammosteids are oval in outline. In Schizosteus, Pycnosteus, Tartuosteus, and Ganosteus they have a deep posterior notch. In Psammolepis this notch existed in young individuals, in adult forms the notch as well as the major part of the plate was covered with tesserae (only in Psl. venyukovi tesserae on the ventral plate are absent). The ventral plate of Psammosteus is entirely covered with tesserae.

In the earliest psammosteids of the Main Devonian Field, those of the Pärnu time, the branchials were long and narrow and the dorsal plate was oblong, with the growth centre placed in its middle. In Narova time this type of psammosteids was represented by Schizosteus striatus (Gross). Simultaneously there existed another species, Sch. splendens, with an almost circular dorsal plate and wide and long branchials. The broad-bodied psammosteids with long and wide branchials, belonging to the genera Tartuosteus, Pycnosteus, Ganosteus and Psammolepis, dominated in Aruküla and Burtnieki times. Rather contrasting to them was the first known Psammosteus, Ps. bergi, whose body was elongated and the branchials strongly turned backwards, with upturned distal tips. In the Frasnian Gauja time all other genera disappeared and only Psammolepis and Psammosteus persisted. A number of species of Psammolepis: Psl. abavica, Psl. paradoxa and Psl. venyukovi Obr., exhibit some primitive features. Their branchials are long and comparatively narrow, with a narrow ornamented part on the dorsal side. As to Psammosteus of the Gauja age, only a fragment of a dorsal plate has been found (in Latvia). In Amata time the number of Psammosteus species is multiplying and that of Psammolepis diminishing. In Snetnaya and later times there. existed only species of Psammosteus with an elongated body and a relatively thin carapace, not to mention Karelosteus from Snetnaya(?) beds, a genus closely related to Psammosteus.

The next problems concerning the evolution of the Givetian and early Frasnian psammosteids are of great interest: the probable time of appearance of genera and species and their interrelationships.

It was believed previously that in the early Givetian (in Pärnu and Narova times) there existed only one genus, Schizosteus, which had appeared, according to Tarlo (1964) already in the Eifelian. But now the presence of another genus, Psammolepis, in Pärnu beds has been established. Lately a large fragment of a dorsal plate (Pi 910, the Geological Museum of the Estonian Academy of Sciences) with a characteristic ornamentation of Schizosteus toriensis, but covered with tesserae, was discovered in the core of a borehole on the bank of Reiu river, Estonia. It is evident that this species must be referred to Psammolepis (Mark-Kurik, 1968).

Furthermore, a fragment ( $\mathrm{Pi} 395)$ with tubercles very similar to those of Tartuosteus, has been found in the Pärnu stage in Tori on the Pärnu river, Estonia. Therefore, we may assume that at the beginning of the Givetian not only Schizosteus and Psammolepis but also Tartuosteus were already existent.

There are also some indications that Pycnosteus too appeared earlier than in the Aruküla time. In the Narova Stage (Gorodenka, Estonia) fragments with a Pycnosteus-like ornamentation (Pi $9131-3$ ) have been discovered together with remains of Schizosteus striatus and Sch. splendens.

It is conceivable that the development of Pycnosteus, as well as of Ganosteus, whose known members have very complicated forms of tubercles, took place long before the early Givetian, and that both Pycnos- 
teus and Ganosteus existed already in the Pärnu time. They have not been found only because the fish fauna of the Pärnu stage is as yet very poorly known. The same applies to such early but very advanced forms as Psammosteus bergi and Tartuosteus(?) luhai, which evidently represent distinct phyletic lines. Their branchials were more or less strongly curved backwards and the dorsal plates covered with tesserae. Because of its early appearance and complicated structure it is hardly possible that Psammosteus could have derived from any known Psammolepis species, as suggested by Tarlo (1964).

It is thus likely that the psammosteid radiation took place in the Eifelian and that the Givetian genera present already distinct phyletic lines. Direct relationships seem to exist between the following forms: Tartuosteus giganteus and T. maximus, Ganosteus artus and G. stellatus, Psammolepis alata and Psl. undulata, and probably between Psammosteus praecursor and Ps. maeandrinus, in which the first member of each pair could well be ancestral to the second one. Of Pycnosteus three successive species are known: $P$. palaeformis, $P$. pauli and $P$. tuberculatus. In all the mentioned groups, although belonging to different genera, a common developmental trend can be observed. The later species are relatively larger, their ornamentation more complicated and the distal tips of the branchials are directed, as a rule, more backwards. Only in Pycnosteus the branchials underwent peculiar changes, their distal tips having been gradually turned forwards. The ventral plate of Pycnosteus also exhibits a distinct developmental trend. The tesserae, covering its posterior notch, retreated gradually upwards from the ventral surface of the plate (Fig. $2 \mathrm{~B}, \mathrm{C})$, and the edges of the notch formed something like runners which underwent abrasion, being in contact with the substratum. The interrelationships of other psammosteids, as for instance of the majority of the species of Psammolepis, are not quite clear, no intermediate forms having yet been found (e. g. the species from the Burtnieki beds).

The Givetian and Lower Frasnian beds of the Main Devonian Field have yielded a number of plates of younger psammosteid individuals. Although this material is somewhat unequal, representing individuals of different stages, it is of great interest. Taking into consideration not only these isolated plates but also the growth lines in the plates of adult individuals, restorations of young stages of several psammosteids have been made (Fig. 4). Some of these restorations, as well as most of the materials concerning growth lines of psammosteids have been previously published (Obruchev and Mark-Kurik, 1965).

Although somewhat hypothetical, these restorations show that there are three groups of such younger individuals, differing in their body form and in the form of the dorsal plates. The first group, apparently the most primitive one, represented by Schizosteus striatus and all Psammolepis species (with the exception of Psl. abavica) is characterized by a slender body and oblong dorsals, as well as by extremely narrow branchials. In some forms: Psammolepis toriensis, Psl. proia and Psl. paradoxa, the branchials are very similar to those of a young Drepanaspis (cf. Fig. 4 and Gross, 1963, Fig. 9 A, B; Pl. 9, Fig. 3). Psammolepis undulata differs from other species in its bottle-shaped dorsal plate and well-developed lateral angles of the body; Psl. venyukovi, in its broad rostral plate and the widened anteriorly dorsal plate.

To the second group belong the wide-bodied forms, with short and broad dorsal plates. In most of them (Schizosteus splendens, Tartuosteus maximus, Pycnosteus tuberculatus, Ganosteus stellatus) the branchial plates are comparatively wide, with more or less prominent distal tips, 
and vary considerably in shape. In Psammolepis abavica and probably in Schizosteus asatkini the branchial plates may have been narrow, resembling those of Psl. toriensis, Psl. proia and Psl. paradoxa. It must be mentioned that the only known specimen of Schizosteus asatkini (Obruchev, 1940; Obruchev and Mark-Kurik, 1965) consisting of a dorsal, a ventral and a branchial plate in nearly natural juxtaposition, represents a young individual.

The young stage of Psammosteus bergi can be considered as a representative of the third group. Its dorsal plate is rhombic, and the branchials broad, with very well-developed distal tips directed backwards. The body form is somewhat similar to that of Psammolepis undulata.

The investigation of the young individuals and the growth lines shows that already at the early stages of ontogeny there was a great diversity in the form and structure of different psammosteid genera and species. Tartuosteus, Pycnosteus and Ganosteus with their broad bodies differ strikingly from most Psammolepis species with rather narrow bodies. Psammolepis abavica is evidently nearer in body form to the first-named genera, which casts doubt on the correctness of its generic assignment. Schizosteus contains both broad and slender forms, and therefore this genus probably needs revision. As its type species is the broad-bodied Sch. asatkini, the slender forms of Schizosteus should perhaps be referred to a new genus.

The ontogenetic data seem to suggest that the relationships of different psammosteids are rather intricate and can be hardly established at the present insufficient state of knowledge; they also allow to suppose that the radiation of the psammosteid genera, and perhaps even of their species, took place before the Givetian.

\section{REF E R E N C E S}

Gros s W. 1963. Drepanaspis gemuendenensis Schlüter. Neuuntersuchung. Palaeontographica, Bd. 121, Abt. A.

Mark-Kurik E. 1968. New finds of psammosteids (Heterostraci) in the Devonian of Estonia and Latvia, ENSV TA Toimet., Keem. Geol., 17, nr. 4.

Obruchev D. 1940. On some psammosteids from the Leningrad and Baltic Middle Devonian, C. R. Acad. Sci. USSR, vol. 28, No. 8.

Obruchev D. and Mark-Kurik E. 1965. Devonian psammosteids (Agnatha, Psammosteidae) of the USSR. Tallinn. (Summary). - О б у че в Д. и М арк-Курик Ә. 1965. Псаммостеиды (Agnatha, Psammosteidae) девона СССР. Таллин.

T a rlo L. B. H. 1964. Psammosteiformes (Agnatha) - a review with descriptions of new material from the Lower Devonian of Poland, I. General part, Palaeont. Polonica, No. 13.

Academy of Sciences of the USSR.

Institute of Palaeontology

Academy of Sciences of the Estonian SSR.

Received

Institute of Geology

\section{OBRUTSEV, E. MARK-KURIK}

\section{PSAMMOSTEIIDIDE (HETEROSTRACI) EVOLUTSIOONIST}

Artiklis käsitletakse psammosteiidide morfoloogiat, antakse perekondade ja liikide oletatav ilmumisaeg ning näidatakse nende sugulussuhteid. Zivee ajajärgu algul (pärnu eal) esines koos Schizosteus'ega Psammolepis ning nähtavasti ka Tartuosteus, Pycnosteus ja Ganosteus. Zivee ajajärgul esinevad perekonnad kujunesid välja juba varem toi- 
munud radiatsiooni tagajärjel. Ainult mõningate psammosteiidiliikide vahel võib kindlaks teha otseseid sugulussuhteid. Ontogeneetline materjal näitab, et juba individuaalse arenemise varasematel staadiumidel esines psammosteiidide perekondade ja liikide esindajate vahel suuri erinevusi.

\section{Д. ОБРУЧЕВ, Э. МАРК-КУРИК}

\section{ОБ ЭВОЛЮЦИИ ПСАММОСТЕИД (HETEROSTRACI)}

После опубликования нашей монографии (1965) в Прибалтике был собран новый материал по псаммостеидам, что дало возможность сделать ряд новых реконструкций и более подробно охарактеризовать их эволюцию и онтогенез.

Рассмотрены морфология псаммостеид, предполагаемое время появления родов и видов, а также их взаимоотношения. Установлено, что в начале живетского века, в пярнуское время, наряду с Schizosteus существовал Psammolepis и, по-видимому, Tartuosteus. Можно предполагать существование еще Pycnosteus и Ganosteus. Живетские роды представляют отдельные филетические линин. Прямые родственные связи удалось установить только между некоторыми видами псаммостеид.

В живетских и нижнефранских слоях найдены пластинки молодых особей псаммостеид. С помощью их, а также линий нарастания пластинок взрослых особей сделаны реконструкции молодых псаммостеид. Онтогенетический материал показывает, что уже на более ранних стадиях развития между родами и видами псаммостеид существовали значительные различия.

Изложенгый материал показывает, что радиация родов и, возможно, видов псаммостеид происходила до живетского века. 